\title{
FAKTOR-FAKTOR YANG MEMPENGARUHI KEJADIAN HIPERTENSI PADA KEHAMILAN TRIMESTER III DI KABUPATEN BANJARNEGARA
}

\author{
Umi Nur Fajri ${ }^{1}$, Dian Nirmala Sari ${ }^{2}$ \\ Prodi DIII Kebidanan Politeknik Banjarnegara, Jawa Tengah, Indonesia \\ Email corresponding:umibna62@gmail.com \\ (Diterima 27-10-2019; disetujui 19-11-2019; dipublish 27-11-2019)
}

\begin{abstract}
Abstrak
Hipertensi adalah masalah yang paling sering dalam kehamilan. Hipertensi merupakan 5 - 10\% komplikasi dalam kehamilan dan merupakan salah satu dari penyebab kematian tersering selain perdarahan dan infeksi, dan juga banyak memberikan kontribusi pada morbiditas dan mortalitas ibu hamil. Penelitian ini dilakukan untuk mengetahui faktor- faktor yang mempengaruhi kejadian hipertensi pada ibu Hamil Trimester III. Desain studi analitik dengan pendekatan cross sectional, dengan menggunakan data sekunder. Subjek penelitian adalah ibu hamil trimester III di Kabupaten Banjarnegara sebanyak 60 responden.Pendidikan sebagian besar pendidikan rendah dan hipertensi sebesar 23 responden $(51,1 \%)$. Pekerjaan sebagian besar tidak bekerja dan tidak hipertensi yaitu 25 $(55,6 \%)$. Untuk umur responden sebagian berisiko dan mengalami hipertensi yaitu 10 (83,3\%). Paritas sebagian responden multiparitas dan luka mengalami hipertensi yaitu 25 responden (50\%). Untuk riwayat hipertensi mengalami riwayat hipertensi dan terjadi hipertensi yaitu 30 (50\%). Faktor pendidikan, pekerjaan, umur, paritas, riwayat hipertensipengaruh terhadap kejadian hipertensi. Tetapi variabel yang paling berpengaruh yaitu umur dan riwayat hipertensi dengan nilai $p$ value 0,010 dan 0,000 .
\end{abstract}

Kata Kunci:Hipertensi, Kehamilan Trimester III, Faktor resiko

\begin{abstract}
Hypertension is the most frequent problem in pregnancy. Hypertension is a 5-10\% complication in pregnancy and is one of the most common causes of death besides bleeding and infection, and also contributes a lot to the morbidity and mortality of pregnant women. This study was conducted to determine the factors that influence the incidence of hypertension in Trimester III pregnant women. Analytic study design with cross sectional approach, using secondary data. Subjects were 60 third trimester pregnant women in Banjarnegara District. Education mostly low education and hypertension by 23 respondents (51.1\%). Most of the work is not working and not hypertension, 25 (55.6\%). For the age of the respondents, some of them were at risk and had hypertension, 10 (83.3\%). The parity of some multiparity respondents and hypertensive injuries was 25 respondents (50\%). For a history of hypertension, there is a history of hypertension and hypertension is 30 (50\%). Educational factors, occupation, age, parity, history of hypertension influence on the incidence of hypertension. But the most influential variables are age and history of hypertension with $p$ values of 0.010 and 0.000 . Keywords: Hypertension, Trimester III Pregnancy, Risk factors
\end{abstract}

\section{PENDAHULUAN}

Hipertensi termasuk dalam masalah global yang melanda dunia. Menurut data WHO (World Health Organization) pada tahun 2012 jumlah kasus hipertensi ada 839 juta kasus. Kasus ini diperkirakan akan semakin tinggi pada tahun 2025 dengan jumlah 1.15 milyar kasus atau sekitar 29\% dari total penduduk dunia. Secara global, $80 \%$ kematian ibu hamil yang tergolong dalam penyebab kematian ibu secara tidak langsung yaitu disebabkan karena perdarahan (25\%), hipertensi pada ibu hamil (12\%), partus macet $(8 \%)$, aborsi $(13 \%)$, dan sebab lain $(7 \%)^{1}$. Hipertensi merupakan manifestasi gangguan hemodinamik sistem kardiovaskular, yang penyebabnya adalah multi faktor sehingga tidak bisa diterangkan dengan hanya satu mekanisme tunggal. Hipertensi adalah masalah medik yang cukup sering didapatkan pada kehamilan, dengan angka kejadian sekitar $2-4 \%{ }^{2}$. Penyebab pasti hipertensi pada ibu hamil masih belum 
diketahui secara pasti, sehingga hipertensi disebut sebagai "the disease of theories". Beberapa faktor risiko terjadinya preeklampsia meliputi: primagravida, primipaternitas, hiperplasentosis (mola hidatidosa, kehamilan multipel, diabetes mellitus, bayi besar), riwayat keluarga pernah preeklampsia/eklampsia, penyakitpenyakit ginjal yang sudah ada sebelum hamil ${ }^{3}$.

\section{METODE PENELITIAN}

Teknik sampling dalam penelitian ini adalah non probability sampling jenis consecutive sampling, yaitu semua subjek memenuhi kriteria dimasukkan dalam penelitian sampai jumlah subjek yang diperlukan terpenuhi. Penelitian ini dilakukan diPuskesmas yang ada di Kabupaten Banjarnegara menggunakan desain studi analitik dengan metode cross sectional, pada bulan juli- agustus 2019.Subjek penelitian adalah Ibu hamil trimester trimester III yang melakukan di Puskesmas wilayah Kabupaten Banjarnegara.

\section{HASIL PENELITIAN}

Karakteristik dalam penelitian ini terdiri dari pendidikan, pekerjaaan, umur, paritas , riwayat hipertensi dan kejadian hipertensi

Tabel 1. Karakteristik responden

\begin{tabular}{|c|c|c|c|c|c|c|}
\hline \multirow{3}{*}{ Variabel } & \multicolumn{4}{|c|}{ Hipertensi } & \multicolumn{2}{|c|}{ Total } \\
\hline & \multicolumn{2}{|c|}{$\mathrm{Ya}$} & \multicolumn{2}{|c|}{ Tidak } & \multirow[b]{2}{*}{$\mathrm{N}$} & \multirow[b]{2}{*}{$\%$} \\
\hline & $\mathrm{N}$ & $\%$ & $\mathrm{~N}$ & $\%$ & & \\
\hline \multicolumn{7}{|l|}{ Pendidikan } \\
\hline $\begin{array}{l}\text { Pendidikan } \\
\text { rendah }\end{array}$ & 23 & 51,1 & 22 & 48,9 & 45 & 75 \\
\hline $\begin{array}{l}\text { Pendidikan } \\
\text { sedang }\end{array}$ & 5 & 45,5 & 6 & 54,5 & 11 & $\begin{array}{l}18 \\
, 7\end{array}$ \\
\hline $\begin{array}{l}\text { Pendidikan } \\
\text { tinggi }\end{array}$ & 2 & 50 & 2 & 50 & 4 & $\begin{array}{l}6, \\
7\end{array}$ \\
\hline \multicolumn{7}{|l|}{ Pekerjaan } \\
\hline Bekerja & 10 & 66,7 & 5 & 33,3 & 15 & 25 \\
\hline Tidak bekerja & 20 & 44,4 & 25 & 55,6 & 45 & 75 \\
\hline \multicolumn{7}{|l|}{ Umur } \\
\hline Berisiko & 10 & 83,3 & 2 & 16,7 & 30 & 50 \\
\hline Tidak & 20 & 41,7 & 28 & 58,3 & 30 & 50 \\
\hline \multicolumn{7}{|l|}{ Berisiko } \\
\hline \multicolumn{7}{|l|}{ Paritas } \\
\hline Primi & 4 & 44,4 & 5 & 55,6 & 9 & 15 \\
\hline Multi & 25 & 50 & 25 & 50 & 50 & 83 \\
\hline Grande & 1 & 100 & 0 & 0 & 1 & ,3 \\
\hline \multicolumn{7}{|l|}{ Riwayat } \\
\hline Hipertensi & & & & & & \\
\hline $\mathrm{Ya}$ & 30 & 100 & 0 & 0 & 30 & 50 \\
\hline Tidak & 0 & 0 & 30 & 100 & 30 & 50 \\
\hline
\end{tabular}

Berdasarkan hasil penelitian di atas pendidikan sebagian besar pendidikan rendah dan hipertensi sebesar 23 responden (51,1\%). Pekerjaan sebagian besar tidak bekerja dan tidak hipertensi yaitu 25 (55,6\%). Untuk umur responden sebagian berisiko dan mengalami hipertensi yaitu $10(83,3 \%)$. Paritas sebagian responden multiparitas dan luka mengalami hipertensi yaitu 25 responden (50\%). Untuk riwayat hipertensi mengalami riwayat hipertensi dan terjadi hipertensi yaitu 30 (50\%).

Tabel 2. Uji Hubungan Pendidikan, Pekerjaan, Umur, Paritas, Riwayat Hipertensi dengan Kejadian Hipertensi Pada Ibu Hamil

\begin{tabular}{|c|c|c|c|c|c|}
\hline \multirow{3}{*}{ Variabel } & \multicolumn{4}{|c|}{ Hipertensi } & \multirow{3}{*}{$\begin{array}{c}P- \\
\text { value }\end{array}$} \\
\hline & \multicolumn{2}{|c|}{$\mathrm{Ya}$} & \multicolumn{2}{|c|}{ Tidak } & \\
\hline & $\mathrm{N}$ & $\%$ & $\mathrm{~N}$ & $\%$ & \\
\hline \multicolumn{6}{|l|}{ Pendidikan } \\
\hline $\begin{array}{l}\text { Pendidikan } \\
\text { rendah }\end{array}$ & 23 & 51,1 & 22 & 48,9 & \multirow{3}{*}{0,945} \\
\hline $\begin{array}{l}\text { Pendidikan } \\
\text { sedang }\end{array}$ & 5 & 45,5 & 6 & 54,5 & \\
\hline $\begin{array}{l}\text { Pendidikan } \\
\text { tinggi }\end{array}$ & 2 & 50 & 2 & 50 & \\
\hline \multicolumn{6}{|l|}{ Pekerjaan } \\
\hline Bekerja & 10 & 66,7 & 5 & 33,3 & \multirow[t]{2}{*}{0,136} \\
\hline $\begin{array}{l}\text { Tidak } \\
\text { bekerja }\end{array}$ & 20 & 44,4 & 25 & 55,6 & \\
\hline \multicolumn{6}{|l|}{ Umur } \\
\hline Berisiko & 10 & 83,3 & 2 & 16,7 & \multirow[t]{3}{*}{0,010} \\
\hline Tidak & 20 & 41,7 & 28 & 58,3 & \\
\hline Berisiko & & & & & \\
\hline \multicolumn{6}{|l|}{ Paritas } \\
\hline Primi & 4 & 44,4 & 5 & 55,6 & \multirow{3}{*}{0,574} \\
\hline Multi & 25 & 50 & 25 & 50 & \\
\hline Grande & 1 & 100 & 0 & 0 & \\
\hline \multicolumn{6}{|l|}{$\begin{array}{l}\text { Riwayat } \\
\text { Hipertensi }\end{array}$} \\
\hline $\mathrm{Ya}$ & 30 & 100 & 0 & 0 & \multirow[t]{2}{*}{0,000} \\
\hline Tidak & 0 & 0 & 30 & 100 & \\
\hline
\end{tabular}

Berdasarkan tabel 2 di atas hasil uji statistic pendidikan, pekerjaan, paritas dengan kejadian hipertensi pada ibu hamil TM III nilai $p$ value lebih dari 0,005 yang berarti tidak ada hubungan antara pendidikan, pekerjaan, paritas dengan kejadian hipertensi pada ibu hamil TM III. Sedangkan untuk variabel umur dan riwayat hipertensi dengan kejadian hipertensi pada ibu hamil TM III $p$ value kurang 0,005 yang berarti ada hubungan terhadap kejadian hipertensi.

Tabel 3. Uji Pengaruh antara Pendidikan, Pekerjaan, Umur, Paritas, Riwayat Hipertensi dengan Kejadian Hipertensi Pada Ibu Hamil

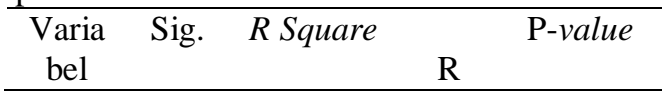




\begin{tabular}{lclll}
\hline Pendi & 0,62 & 1, & 1 & 0 \\
dikan & 1 & 00 &, &, \\
Peker & 0,13 & 0 & 0 & 0 \\
jaan & 6 & & 0 & 0 \\
Umur & 0,01 & & 0 & 0 \\
Parita & 0 & & & $*$ \\
s & 0,75 & & \\
Riwa & 3 & & \\
yat & 0,00 & & \\
Hiper & 0 & & \\
tensi & & &
\end{tabular}

Berdasarkan tabel 5.3 diatas didapatkan bahwa seluruh variabel pendidikan, pekerjaan, umur, paritas, riwayat hipertensi pengaruh terhadap kejadian hipertensi. Tetapi variabel yang paling berpengaruh yaitu umur dan riwayat hipertensi dengan nilai $p$ value 0,010 dan 0,000 .

\section{PEMBAHASAN}

1. Pendidikan dengan kejadian hipertensi pada ibu hamil TM III

Berdasarkan hasil uji statistik pendidikan dengan kejadian hipertensi pada ibu hamil TM III nilai $p$ value lebih dari 0,005 yang berarti tidak ada hubungan antara Pendidikan dengan kejadian hipertensi pada ibu hamil TM III . Hal ini disebabkan karena dalam penelitian ini responden yang menderita hipertensi yang berpendidikan rendah belum tentu memiliki pengetahuan yang rendah pula, karena pengetahuan tidak hanya dipengaruhi oleh pendidikan tapi pengalaman dan pengetahuan yang didapatkan dari bidan pada saat mengikuti kelas ibu hamil. Hasil penelitian ini sesuai dengan hasil penelitian yang dilakukan oleh Nuning Saraswati, Mardiana tahun 2016) bahwa pendidikan tidak berhubungan dengan kejadian preeklamsi pada ibu hamil 4.

2. Pekerjaan dengan kejadian hipertensi pada ibu hamil TM III

Berdasarkan hasil uji statistik pendidikan dengan kejadian hipertensi pada ibu hamil TM III nilai $p$ value lebih dari 0,005 yang berarti tidak ada hubungan pendidikan dengan kejadian hipertensi pada ibu hamil TM III. Ibu hamil yang mengalami hipertensi sebagian besar $(44,4 \%)$ adalah tidak bekerja atau menjadi ibu rumah tangga. Hal ini sesuai dengan penelitian yang dilakukan oleh Nuning Saraswati, Mardiana tahun 2016) bahwa pekerjaan tidak berhubungan dengan kejadian preeklamsi pada ibu hamil ${ }^{4}$.
3. Umur dengan kejadian hipertensi pada ibu hamil TM III

Berdasarkan hasil uji statistik umur dengan kejadian hipertensi pada ibu hamil TM III nilai $p$ value kurang dari 0,005 yang berarti ada hubungan antara umur dengan kejadian hipertensi pada ibu hamil TM III. Dalam penelitian ini dapat disebabkan karena umur dengan kejadian hipertensi pada ibu hamil TM III. Hasil penelitian ini membuktikan teori yang menyatakan bahwa umur merupakan salah satu faktor risiko terjadinya hipertensi dalam kehamilan. Kehamilan pada umur ibu yang ekstrem ( $<20$ dan $>35$ tahun) merupakan kehamilan berisiko tinggi yang dapat menyebabkan komplikasi dalam kehamilan ${ }^{5}$. Hasil penelitian ini juga membuktikan teori yang menyatakan bahwa komplikasi utama kehamilan dibawah umur $<20$ dan $>35$ tahun ini yakni terjadinya preeklampsia. Ibu mengalami hipertensi disertai kaki bengkak dan ditemukan protein pada air seni. ${ }^{6}$ Hal ini sesuai dengan hasil penelitian yang dilakukan oleh Nuning Saraswati, Mardiana (2016) dan Yudhaputra Setiadhi, Shirley E. S. Kawengia, Nelly Mayulu (2016) ${ }^{7}$.

4. Paritas dengan kejadian hipertensi pada ibu hamil TM III

Berdasarkan hasil uji statistik paritas dengan kejadian hipertensi pada ibu hamil TM III nilai $p$ value lebih dari 0,005 yang berarti tidak ada hubungan antara paritas dengan kejadian hipertensi pada ibu hamil TM III. Berdasarkan hasil penelitian multiparitas yang mengalami hipertensi. Hipertensi dapat terjadi pada ibu yang primigravida ataupun yang multigravida. Teori imunologik antara ibu dan janin yang menyatakan bahwa primigravida mempunyai risiko lebih besar terjadinya hipertensi dalam kehamilan (preeklampsia) jika dibandingkan dengan multigravida Hasil peneltian ini tidak sama dengan hasil penelitian yang dilakukan oleh Nuning Saraswati, Mardiana tahun (2016) bahwa paritas berhubungan dengan kejadian preeklamsi pada ibu hamil ${ }^{4}$.

5. Riwayat Hipertensi dengan kejadian hipertensi pada ibu hamil TM III

Berdasarkan hasil uji statistik riwayat hipertensi dengan kejadian hipertensi pada ibu hamil TM III nilai $p$ value kurang dari 0,005 yang berarti ada hubungan antara riwayat hipertensi dengan kejadian hipertensi pada ibu hamil TM III. Hasil sesuai dengan penelitian yang dilakukan 
oleh Ness dkk,dimana di peneltian tersebut didapatkan hasil bahwa risiko terjadinya hipertensi pada ibu hamil yang tidak memiliki riwayat hipertensi pada keluarga lebih rendah dibandingkan yang memiliki riwayat hipertensi pada keluarga. Hal ini sesuai dengan penelitian yang telah dilakukan oleh Yudhaputra Setiadhi, Shirley E. S. Kawengia, Nelly Mayulu (2016) ${ }^{7}$.

6. Faktor - Faktor Berpengaruh Terhadap

Kejadian Hipertensi Pada Ibu Hamil TM III

Faktor Pendidikan, Pekerjaan, Umur, Paritas, Riwayat Hipertensi pengaruh terhadap kejadian hipertensi. Tetapi variabel yang paling berpengaruh yaitu umur dan riwayat hipertensi dengan nilai $p$ value 0,010 dan 0,000 . Hal ini disebabkan pada umur ibu yang ekstrem $(<20$ dan $>35$ tahun) merupakan kehamilan berisiko tinggi yang dapat menyebabkan komplikasi dalam kehamilan dan hipertensi pada ibu hamil yang tidak memiliki riwayat hipertensi pada keluarga lebih rendah dibandingkan yang memiliki riwayat hipertensi pada keluarga hal ini sejalan dengan penelitian yang dilakukan oleh Yudhaputra Setiadhi, Shirley E. S. Kawengia, Nelly Mayulu (2016) bahwa faktor yang paling berpengaruh terhadap kejadian ibu yang mengalami hipertensi karena faktor umur dan memiliki riwayat hipertensi sebelumnya atau riwayat dari keluarganya ${ }^{7}$.

\section{SIMPULAN DAN SARAN}

Faktor pendidikan, pekerjaan, umur, paritas, riwayat hipertensi pengaruh terhadap kejadian hipertensi. Tetapi variabel yang paling berpengaruh yaitu umur dan riwayat hipertensi, disarankan untuk tenaga kesehatan apabila ada ibu hamil yang memiliki umur bereriko dan riwayat hipertensi lebih maksimal untuk melakukan pemantauan agar ibu hamil dapat terdekteksi secara dini.

\section{DAFTAR PUSTAKA}

1. WHO. Data Hipertensi Global;2012.

2. Suhardjono. Buku Ajar Ilmu Penyakit Dalam. Ke-6 E, editor. Jakarta Pusat : Interna Publishing; 2014.

3. Angsar M. Ilmu Kebidanan. Jakarta: Yayasan Bina Pustaka Sarwono Prawirohardjo; 2009.

4. Nuning Saraswati M. Faktor Risiko Yang Berhubungan Dengan Kejadian Preeklampsia Pada Ibu Hamil (Studi Kasus Di RSUD Kabupaten Brebes Tahun 2014). Unnes Journal of Public Health. 2016;5 (2).

5. Norwitz E dan Schorge J. At a Glance Obstetri dan Ginekologi. Jakarta: Erlangga; 2008.

6. Nugroho T. Patologi Kebidanan. Yogyakarta: Nuha Medika; 2012.

7. Setiadhi Y, Kawengian SES, Mayulu N. Analisis Faktor Yang Berhubungan Dengan Kejadian Hipertensi Pada Kehamilan Di Kota Manado. Jurnal e-Biomedik (eBm), 2016;4:4. 